\section{PENERAPAN PRUDENTIAL BANKING PRINCIPLE DALAM UPAYA PERLINDUNGAN HUKUM BAGI NASABAH PENYIMPAN DANA $^{1}$}

Oleh: Toto Octaviano Dendhana ${ }^{2}$

\section{ABSTRAK}

Tujuan penelitian ini adalah untuk mengetahui bagaimanakah penerapan prinsip kehati-hatian pada kegiatan operasional bank, bagaimanakah implementasi prinsip kehati-hatian bank yang diatur oleh Undang-undang Perbankan, dan manfaat apakah yang dapat diperoleh dalam penerapan prinsip kehatihatian dalam kegiatan operasional bank. Dengan menggunakan penelitian hukum normatif disimpulkan bahwa: 1. Bank dalam kegiatan operasional perbankannya harus menerapkan prinsip kehati-hatian (prudential banking) dimana prinsip kehati-hatian dalam mengelola dan menjalankan aktivitas perbankan seharihari, bertujuan untuk menjaga kesehatan bank. 2. Implementasi prinsip kehati-hatian yang diatur melalui UU Perbankan keberadaannya dalam UU No. 7/1992 dan perubahannya yaitu UU No.10/1998 tentang Perbankan, telah diatur secara tegas. 3. Manfaat dengan diterapkannya prinsip kehati-hatian bank, yaitu: (1) Bagi bank pelaksana, dalam melakukan usahanya akan melindungi kepentingan nasabah penyimpan dana khususnya, dapat memberikan pelayanan jasa perbankan yang cepat, murah dan aman sehingga akan meningkatkan kepercayaan masyarakat terhadap bank tersebut sebagai bank yang benar-benar prudent dan solid; (2) Manfaat bagi nasabah, yaitu nasabah dapat memperoleh pelayanan jasa perbankan yang aman, cepat dan

\footnotetext{
1 Artikel skripsi. Dosen pembimbing skripsi: Atie Olii,SH,MH, Dr. Hero Soepeno,SH,MH, Fatmah Paparang, $\mathrm{SH}, \mathrm{MH}$.

2 Mahasiswa Fakultas Hukum Universitas Sam Ratulangi, Manado.
}

menguntungkan bagi transaksinya disamping nasabah akan terbebas dari perasaan was-was, akan nasib simpanannya akibat ditutupnya bank; (3) Manfaat bagi pemerintah; untuk stabilitas moneter.

Kata kunci: prudential banking principle, nasabah

\section{PENDAHULUAN}

\section{A. LATAR BELAKANG}

Norma hukum perbankan yang berlaku di Indonesia khususnya yang terdapat dalam Undang-undang Nomor 10 Tahun 1998 tentang Perubahan Undang-undang No. 7 Tahun 1992 didalamnya terkandung asas atau prinsip yaitu prinsip demokrasi ekonomi, prinsip kehati-hatian, prinsip perbankan yang rnenunjang pembangunan, prinsip perbankan yang menunjang stabilitas, prinsip likuiditas, prinsip profesional.

Pada kenyataannya dalam praktek perbankan dewasa ini, penerapan prinsip kehati-hatian bank (prudential banking principle) yang merupakan andalan bagi upaya peningkatan kepercayaan nasabah dan sekaligus sebagai sarana perlindungan pada masyarakat penyimpan, perlu ditingkatkan untuk mencapai sasaran yang diharapkan. Memang penerapan prinsip kehati-hatian dalam kegiatan operasional perbankan, pada kondisi persaingan perbankan memperebutkan nasabah sebagai konsumen bank saat ini yang semakin kompetitif, sangat diperlukan. Selain itu, penyaluran dana perbankan seperti pemberian kredit atau pembelian surat-surat berharga merupakan bisnis beresiko tinggi, yang apabila tidak dikelola dengan baik dapat mengganggu tidak hanya kelangsungan bank itu sendiri, namun juga sistem perbankan dan kestabilan moneter.

Berdasarkan uraian tersebut kiranya menarik untuk dikaji aspek hukum penerapan prinsip kehati-hatian dalam kegiatan operasional bank, untuk kemudian 
dianalisis dan dituangkan dalam bentuk karya ilmiah yaitu skripsi.

\section{B. PERUMUSAN MASALAH}

1. Bagaimanakah penerapan prinsip kehati-hatian pada kegiatan operasional bank?

2. Bagaimanakah implementasi prinsip kehati-hatian bank yang diatur oleh Undang-undang Perbankan?

3. Manfaat apakah yang dapat diperoleh dalam penerapan prinsip kehati-hatian dalam kegiatan operasional bank ?

\section{METODE PENELITIAN}

Penelitian ini menggunakan metode penelitian yang termasuk jenis penelitian normatif, dengan beranjak pada asas-asas yang melandasi kehidupan perbankan dan peraturan perundang-undangan yang mengatur kehidupan perbankan.

\section{TINJAUAN PUSTAKA}

\section{A. PENGERTIAN BANK}

Menurut UU No. 10 Tahun 1998 tanggal 10 November 1998 tentang Perbankan, yang dimaksud dengan Bank adalah "Badan usaha yang menghimpun dana dari masyarakat dalam bentuk simpanan dan menyalurkannya kepada masyarakat dalam bentuk kredit dan atau bentuk lainnya dalam rangka meningkatkan taraf hidup rakyat banyak". ${ }^{3}$

\section{B. ASPEK HUKUM PENGATURAN BANK}

Apa yang dimaksud dengan hukum perbankan itu? Secara sederhana hukum perbankan adalah hukum positif yang mengatur segala sesuatu yang menyangkut tentang bank. Bank merupakan salah satu lembaga keuangan yang fungsi utamanya sebagai penghimpun dan penyalur dana yang berlaku. Ini berarti kita akan membicarakan hukum yang berlaku saat ini

\footnotetext{
${ }^{3}$ Kasmir, Bank \& Lembaga Keuangan Lainnya, PT. Raja Grafindo Persada, Jakarta, 2002, hlm. 23.
}

yang mengatur segala sesuatu yang menyangkut tentang bank. ${ }^{4}$

\section{PRINSIP KEHATI-HATIAN BANK}

Istilah prinsip dalam bahasa Inggris disebut Principle diartikan sebagai dasar, sehingga menggunakan asas dalam asas hukum berarti fondasi atau landasan dari suatu aturan hukum. Black dalam bukunya memberikan pengertian principle sebagai berikut $A$ fundamental truth or doctrine, as of law....

Suatu prinsip adalah suatu pernyataan atau suatu kebenaran yang pokok, yang memberikan suatu petunjuk kepada pemikiran atau tindakan. ${ }^{6}$ Penerapan prinsip kehati-hatian bank merupakan dasar untuk menjalankan kegiatan operasional bank.

Istilah kehati-hatian dalam Bahasa Inggris dapat dipadankan dengan care sebagai kata benda dan carefull kata sifat. Sedang kata prudent sebagai kata sifat diartikan sebagai bijaksana atau hati-hati. ${ }^{7}$ Menurut Black istilah prudent diartikan sebagai "Sagacious in adapting means to end; circumspect in action, or in deterneming any line of conduct. Practically wise, judicious, cereful, discreet, circumpect, sensible... in defineng neglegence, practically synonymous with caution". ${ }^{\prime}$

Bila melihat tulisan yang membahas perbankan maka prinsip kehati-hatian diambil dari istilah prudent yang dalam tulisan-tulisan tersebut diistilahkan sebagai prudential banking. Di samping itu ada pula

\footnotetext{
${ }^{4}$ Rachmadi Usman, Aspek-aspek Hukum Perbankan Di Indonesia, PT. Gramedia Pustaka Utama, Jakarta, 2001, hlm. 2.

5 Henry Campbell Black, Black's Law Dictionary, St. Paul Minn, Sixth Edition, 1990, hlm. 1193.

6 Moekidjat, Kamus Manajemen. Mandar Maju, Bandung, 1990, hlm. 413.

7 Echols John, M dan Hassan Shadily, Kamus Inggris Indonesia, Penerbit PT Gramedia Pustaka Utama, Jakarta, 1997, hlm. 454.

${ }^{8}$ Henry Campbell Black, Op.Cit, hlm. 1226.
} 
tulisan yang menggunakan istilah prudential regulation yang diartikan sebagai prinsip kehati-hatian bank pada saat membicarakan tingkat kesehatan bank. ${ }^{9}$

Istilah-istilah yang digunakan dalam berbagai tulisan ditanggapi oleh Sjahdeini sebagai berikut : prinsip kehati-hatian oleh Undang-undang perbankan 1992 telah diambil sebagai terjemahan dari prudential principle yang sudah dikenal dikalangan perbankan. ${ }^{10}$ Terjemahan itu tidak tepat, seharusnya prudential diterjemahkan kedalam Bahasa Indonesia dengan arif, sedangkan prudentiality principle seyogyanya diterjemahkan dengan prinsip kearifan.

Bank Indonesia dalam menerjemahkan prudential banking ke dalam Bahasa Indonesia sebagai prinsip kehati-hatian. Hal ini dicantumkan di dalam peraturanperaturan yang dikeluarkan oleh Bank Indonesia. Bila dilihat pada pasal-pasal dalam UU No. 7 Tahun 1992 dan perubahannya dalam UU No. 10 Tahun 1998 ditemukan istilah prinsip kehatihatian seperti tersebut dalam Pasal 2, Pasal 29 ayat (2) UU No. 7 Tahun 1992 tentang Perbankan berikut perubahannya dalam UU No. 10 Tahun 1998 tentang Perbankan, serta penjelasan-penjelasan yang terdapat dalam kedua undang-undang tersebut.

Pengertian kedua istilah tersebut tidak ditemukan baik didalam UU No. 7 Tahun 1992, UU No. 10 Tahun 1998 maupun peraturan-peraturan perbankan lainnya. Oleh sebab itu menyimak isi yang tercantum dalam kedua undang-undang perbankan, dapatlah dikatakan bahwa prinsip kehati-hatian adalah berkaitan dengan aktivitas atau kegiatan perbankan dalam menjalankan operasionalnya sehingga melalui penerapan prinsip

\footnotetext{
${ }^{9}$ Widjanarto, Hukum Dan Ketentuan Perbankan di Indonesia. Grafiti Jakarta, 1977, hlm. 140.

${ }^{10}$ Sutan Remy Sjahdeini, Kebebasan Berkontrak dan Perlindungan Yang Seimbang Bagi Para Pihak Dalam Perjanjian Kredit Bank Di Indonesia, Institut Bankir Indonesia, Jakarta, 1993, hlm. 174.
}

tersebut diharapkan dapat tercipta kondisi atau keadaan bank yang sehat dan berfungsi dengan baik.

\section{PEMBAHASAN}

\section{A. PENERAPAN PRINSIP KEHATI-HATIAN PADA KEGIATAN OPERASIONAL BANK}

Pada dunia perbankan di Indonesia, sejak dikeluarkannya Pakto 1988, pertumbuhan bank di Indonesia sungguh sangat pesat. Sayangnya pertumbuhan bank itu ternyata tidak diikuti manajemen dan kualitas dan kinerja yang baik. Pencabutan izin usaha 16 (enam belas) bank swasta nasional tahun 1997 yang dilakukan oleh pemerintah karena dinilai tidak dapat diselamatkan lagi. Hal ini dilakukan dengan bertujuan untuk menciptakan kondisi perbankan yang sehat dl Indonesia. Memang perkembangan perbankan setelah Pakto 1988 ini sangat pesat tetapi kurang terkontrol, sehingga menimbulkan berbagai masalah dalam praktek, dan prinsip Prudent Banking sama sekali diabaikan.

Krisis berat yang dialami dunia perbankan Indonesia pada pertengahan 1997, telah memaksa pemerintah mengambil kebijakan drastis di sektor perbankan antara lain adalah dengan mencabut ijin usaha sejumlah bank yang bermasalah. Namun, oleh karena tidak adanya peraturan yang cukup mengatur perlindungan nasabah penyimpan pada saat bank dilikuidasi telah mengakibatkan hilangnya kepercayaan masyarakat terhadap industri perbankan. Ketika ijin usaha 16 bank dicabut dan dilikuidasi pada 1 Nopember 1997 industri perbankan mengalami rush sebagai konsekuensi runtuhnya kepercayaan masyarakat terhadap perbankan nasional.

Perhatian terhadap penerapan prinsip kehati-hatian dengan tujuan untuk menjaga kesehatan bank pada masa sekarang ini, sangatlah dibutuhkan karena mengingat 
adanya tragedi perbankan nasional tersebut diatas. Maraknya dunia perbankan tersebut, adalah wujud dari berkembangnya perangkat pengaturan bidang perbankan, sebagai instrumen pemerintah dalam menjalankan kebijakan di bidang perekonomian dalam mengejar pertumbuhan ekonomi.

Kenyataan

bertahun-tahun

membuktikan bahwa bank merupakan simbol kepercayaan masyarakat terhadap kondisi moneter suatu negara. Begitu besarnya kepercayaan masyarakat terhadap bank, sehingga sebuah bank menderita sakit sedikit saja, pengaruhnya cukup terasa bagi sendi-sendi perekonomian negara. Manakala kondisi kesehatan. suatu bank diragukan, hal ini akan membawa akibat kerugian tidak hanya kepada nasabah atau masyarakat penyimpan dana dan debitornya, tetapi dunia perbankan pada umumnya.

Penerapan prinsip kehati-hatian dan kesehatan bank tidak terlepas dari pengaturan berbagai pihak yang terlibat dalam dunia perbankan tersebut. Kepentingan utama ada pada negara. Campur tangan negara dapat dilihat dalam berbagai aspek, yaitu aspek politik hukum, aspek perizinan dan aspek usaha langsung. Dengan politik hukum pemerintah mengendalikan perbankan lewat pembentukan hukum di bidang perbankan, dilihat dari aspek perizinan pemerintah mengendalikan bank lewat perizinan, dan dilihat dari aspek usaha langsung maka pemerintah terjun langsung kedalam dunia perbankan dengan mendirikan bank pemerintah. Adanya bank pemerintah maka dapatlah dikatakan bahwa bank ini mempunyai dua fungsi yaitu sebagai financial intermediary dan sebagai agent of development .

Masyarakat pengusaha juga sangat berkepentingan, dimana bank adalah bidang usaha jasa keuangan yang menjanjikan keuntungan. Disamping kepentingan masyarakat pengusaha ada pula kepentingan lain yaitu kepentingan masyarakat umum, hal ini dikarenakan lembaga bank adalah lembaga yang dapat memberikan pelayananan jasa keuangan.

Dengan demikian terlihat bahwa dalam dunia perbankan terdapat tiga pihak utama yang sangat berkepentingan, yaitu kepentingan negara dalam hal ini pemerintah (kepentingan pembangunan), kepentingan pengusaha bank, dan kepentingan masyarakat atau nasabah.

Perwujudan ketiga kepentingan tersebut dalam lingkungan perbankan dapat terlihat dari keberadaan mereka sebagai pihakpihak yang terlibat langsung dalam dunia perbankan, yaitu pertama, pihak Bank Indonesia sebagai Bank Sentral, kedua pihak bank pelaksana (bank pemerintah maupun bank swasta), ketiga pihak nasabah bank baik sebagai penyimpan dana ataupun yang menerima dana.

Hubungan ketiga pihak dalam dunia perbankan dapat terjalin dengan baik, apabila hubungan ketiganya secara khusus berfondasikan atas asas-asas pergaulan dalam bidang perbankan yang antara lain melalui penerapan prinsip kehati-hatian dalam menjalankan kegiatan operasional bank, sehingga bank tersebut sehat, tumbuh dan berkembang dalam kehidupan dunia perbankan. Asas-asas perbankan yang melingkupi kehidupan dunia perbankan, dalam pengertian menuntun sikap para pihak yang terlibat dalam dunia perbankan, dengan suatu pemikiran bahwa asas-asas tersebut adalah demi dan untuk kehidupan dunia perbankan yang baik.

Melihat hat tersebut di atas maka dapat dikatakan bahwa hubungan antara Bank Indonesia dengan bank pelaksana dan nasabah dilandasi oleh asas pengayoman, sedangkan hubungan antara bank pelaksana dengan nasabah didasarkan kepada asas kemitraan. Asas kemitraan ini dikembangkan dalam hubungan antara nasabah dan bank, melalui asas 
kepercayaan, asas kerahasiaan, asas kehatihatian. Seluruh jalinan hubungan yang dilandasi oleh asas-asas tersebut diarahkan untuk menciptakan sistem perbankan yang sehat yang memberikan kenyamanan dan kepastian hukum para pihak dalam melaksanakan transaksi perbankan.

Aktivitas usaha bank, terutama dalam kegiatan menghimpun dan menyalurkan dana dari dan ke masyarakat, penerapan prinsip kehati-hatian dan kesehatan bank menjadi sangat penting didalam operasional perbankan tersebut. Dengan demikian bank tidak boleh seenaknya dalam mengolah dana-dana nasabah.

Dana yang berasal dari masyarakat merupakan suatu tulang punggung (basic) dari dana yang harus diolah atau dikelola oleh bank untuk memperoleh keuntungan. Pertumbuhan suatu bank sesungguhnya sangat bergantung dari pertumbuhan dana yang berasal dari simpanan masyarakat.

Bank dalam melaksanakan kegiatannya haruslah menjadikan dana masyarakat sebagai pertimbangan utama dengan demikian kegiatan tersebut dapat membawa keuntungan baik kepada bank itu sendiri maupun kepada nasabah, yang secara otomatis dana masyarakat menjadi aman.

Dengan adanya pertimbangan yang masak mengenai dana masyarakat yang dikelola oleh bank maka menempatkan bank pada posisi yang harus secara khusus melakukan kegiatan secara hati-hati. Karena siapapun tidak dapat menyangkal bahwa operasional perbankan sebagian besar mengolah dana masyarakat, yang tidak lain merupakan fungsi dari perbankan itu sendiri. Hubungan bank dan nasabah penyimpan dana adalah hubungan kontraktual antara debitur dan kreditur yang dilandasi prinsip kehati-hatian.

Tujuan dari prinsip kehati-hatian ini agar bank yang menggunakan uang nasabah itu akan mampu membayar kembali dana masyarakat yang disimpan kepadanya apabila ditagih oleh para penyimpannya.
Penerapan prinsip kehati-hatian menjadi pegangan atas kepercayaan masyarakat terhadap lembaga perbankan. Wujud dari kepercayaan itu adalah berupa adanya masyarakat yang menyimpan uangnya pada bank, oleh karena itu jika tidak berhati-hati mengelola dana tersebut maka akan melunturkan kepercayaan nasabah. Jika sudah luntur maka akan sulit untuk membangun kembali kepercayaan tersebut.

Bank yang sehat akan mewujudkan kepercayaan masyarakat untuk menyimpan dananya, sedangkan bank dalam menjalankan usahanya membutuhkan dana yang cukup. Oleh sebab itu prinsip kehatihatian dalam dunia perbankan menjadi hal yang sangat mendasar untuk mewujudkan bank yang sehat.

Perkembangan industri perbankan yang pesat, menyebabkan bank-bank baru bermunculan dan membuat persaingan semakin tajam. Tingkat kesehatan bank dapat digunakan sebagai alat pemantau kebijaksanan bank sentral terhadap bank umum. Konsekuensi dari tidak terpenuhinya persyaratan untuk dapat dikatakan bank yang sehat tidak hanya menyempitya keleluasaan yang dimiliki oleh bank tetapi tingkat kepercayaan masyarakat penyimpan dana menurun.

Penurunan kepercayaan masyarakat pada suatu bank, akan menyebabkan penarikan dana secara besar-besaran oleh nasabah bank tersebut, padahal secara operasional perbankan, bank-bank biasanya hanya menyisakan sebagian kecil dari simpanan yang diterimanya untuk berjaga-jaga apabila ada penarikan dana oleh nasabahnya. Karena bagian terbesar dari dana bank dialokasikan sebagai pemberian kredit. Hal ini dapat menyebabkan bank tidak dapat memenuhi permintaan dalam jumlah besar dengan segera atas simpanan nasabah yang dikelolanya, bila terjadi penarikan secara tiba-tiba dan dalam jumlah besar. Keterbatasan dalam penyediaan dana Cash 
ini, karena bank tidak dapat menarik segera pinjaman yang telah disalurkannya kepada debitor.

Bila bank tidak dapat memenuhi permintaan penarikan simpanan oleh nasabahnya dalam keadaan tersebut, nasabah biasanya menjadi panik dan akan menutup rekeningnya pada bank, sekalipun bank tersebut sebenarnya sehat. ${ }^{11}$

Untuk itulah stabilitas dalam pengelolaan kegiatan operasional bank sangat dibutuhkan untuk menciptakan kepercayaan dari nasabah bank, guna mencegah kepanikan nasabah dengan jalan meyakinkan nasabah tentang keamanan dana simpanannya, melalui pengelolaan bank yang berpedoman kepada prudential banking system.

Penerapan prinsip kehati-hatian bank akan dapat memberikan perlindungan terhadap kepentingan nasabah. Agar perlindungan ini benar-benar memberikan rasa aman kepada masyarakat penyimpan dana atau nasabah maka perlu adanya penilaian kesehatan bank.

Untuk menilai kesehatan bank dapat dilihat dari berbagai segi. Penilaian ini bertujuan untuk menentukan apakah bank tersebut dalam kondisi yang sehat, cukup sehat, kurang sehat dan tidak sehat, sehingga Bank Indonesia sebagai pengawas dan pembina bank-bank dapat memberikan arahan atau petunjuk bagaimana bank tsb. harus dijalankan atau bahkan dihentikan kegiatan operasionalnya. $^{12}$

Mengenai penerapan prinsip kehatihatian dikemukakan bahwa :

Dengan memperhatikan prinsip kehatihatian itu, maka diharapkan perbankan Indonesia dalam melakukan usahanya akan melindungi kepentingan masyarakat penyimpan dana khususnya

\footnotetext{
${ }^{11}$ Zulkarnain Sitompul, Penjaminan Dana Nasabah Bank, Jurnal Hukum Bisnis, No. 22, 2003, hlm. 78.

${ }^{12}$ Kasmir, Loc.Cit, hlm. 46-47.
}

serta nenunjang kegiatan eknomi pada umumnya, bahkan lembaga perbankan diharapkan dituntut mampu menciptakan stabilitas nasional dalam arti yang seluas-luasnya. ${ }^{13}$

Adanya keterkaitan yang erat antara asas kehati-hatian, kepercayaan dan kesehatan bank tersebut, hal ini tentunya memiliki hubungan secara khusus terhadap kerangka perlindungan terhadap dana masyarakat, dalam hal nasabah penyimpan dana yang telah menyimpan uangnya pada bank tersebut. Dengan demikian berarti prinsip kehati-hatian dipandang harus menjadi landasan bekerjanya bank, justru dalam kerangka memberikan perlindungan terhadap dana yang telah disimpan masyarakat.

\section{B. IMPLEMENTASI PRINSIP KEHATI- HATIAN BANK MELALUI UNDANG- UNDANG PERBANKAN}

Implementasi prinsip kehati-hatian bank yang diatur oleh Undang-undang Perbankan bila dilihat, mengenai hal ini sebenarnya telah dinyatakan dengan tegas keberadaannya dalam UU No. 7 Tahun 1992 tentang Perbankan dan perubahannya yaitu

UU No. 10 Tahun 1998 tentang Perbankan, kemudian terdapat beberapa ketentuan yang terdapat dalam aturanaturan yang dikeluarkan oleh Pemerintah berupa Peraturan Pemerintah maupun Keputusan Presiden dan aturan-aturan yang dikeluarkan oleh Bank Indonesia berupa Surat Keputusan Bank Indonesia yang diwujudkan ke dalam Surat Edaran Bank Indonesia bagi perbankan nasional yang merupakan penjabaran lebih lanjut dari asas kehati-hatian dan kesehatan bank tersebut.

Bank Indonesia dalam rangka pelaksanaan pengaturan perbankan

\footnotetext{
13 Asikin, Pokok-Pokok Hukum Perbankan, PT. Raja Grasindo Persada, Jakarta. 1995, hlm. 7.
} 
berdasarkan prinsip kehati-hatian memberikan suatu

ketentuan sebagai berikut :
a. Kewajiban penyediaan modal minimum
b. Kewajiban memelihara posisi devisa neto setinggi-tingginya $23 \%$ dari modal bank
c. Ketentuan Batas Maksimum Pemberian Kredit (BMPK)
d. Penyisihan penghapusan aktiva produktif
e. Pinjaman komersial luar negeri
f. Ketentuan Loan to Deposit Ratio (LDR) maksimum $110 \%$

g. Kriteria orang-orang tercela yang dilarang menjadi pemegang saham dan atau pengurus bank.

Sementara itu dalam menguraikan prinsip kehati-hatian ketentuan dalam UU No. 10 Tahun 1998 tentang Perbankan, yang merupakan penjabaran dari prinsip kehatihatian tersebut, yaitu :

a. Aspek dasar (lihat Pasal 2);

b. Aspek ketentuan perkreditan (lihat Pasal 8, 11);

c. Aspek perijinan, bentuk hukum dan kepemilikan bank (lihat Pasal 16 sampai Pasal 28);

d. Aspek pembinaan dan pengawasan Bank Indonesia (lihat Pasal 29 sampai Pasal 37).

Berdasarkan hal tersebut, maka penjabaran atau implementasi prinsip kehati-hatian dan kesehatan bank dalam aspek perkreditan dapat diterangkan berikut ini. Aspek perkreditan atau penyaluran dana oleh bank telah banyak mendapatkan porsi dalam UU No. 7 Tahun 1992 tentang Perbankan dan perubahannya dalam UU No. 10 Tahun 1998 tentang tentang Perbankan, sebagaimana yang termuat dalam :
a. Pasal 1 angka (11) memuat tentang pengertian kredit;

b. Pasal 8 memuat tentang pemberian kredit atau pembiayaan berdasarkan prinsip syariah dengan kewajiban menganalisis dengan prinsip perkreditan.

c. Pasal 11 tentang batas maksimum pemberian kredit.

Di samping ketentuan pokok tersebut, juga ada beberapa ketentuan lain dalam pelaksanaan pemberian kredit, yaitu ketentuan dari proses pemberian kredit sampai kepada upaya mengatasi kredit yang mengalami kemacetan. Sehingga dapat dikatakan bahwa aturan hukum dalam kegiatan menyalurkan dana ini mendapat perhatian yang besar dalam UU Perbankan.

Perhatian yang besar terhadap kegiatan penyaluran dana ini, dikarenakan dua hal, yaitu :

a. Aktivitas penyaluran dana (kredit) merupakan tulang punggung kehidupannya, karena hampir semua bank di Indonesia, aset yang dimiliki berwujud pemberian kredit sehingga boleh dikatakan bahwa sebagian besar pendapatan atau hasil operasi bank didominasi oleh pendapatan kredit yang diberikan.

b. Aktivitas penyaluran dana ini di samping menghasilkan bunga, juga berisiko macet. Adanya risiko macet inilah yang dalam tingkat volume tertentu dapat mengganggu kesehatan bank.

Risiko macet dari penyaluran dana dalam bentuk kredit ini harus benar-benar mendapat perhatian pihak perbankan, karena dapat menjadi bumerang yang tidak hanya gagal dalam mengharapkan penghasilan bunga, melainkan akan menghantam keberadaan bank itu sendiri.

Kredit macet dapat terjadi oleh beberapa hal, yaitu :

a. Karena keputusan pemberian kredit yang kurang tepat pada saat kredit diberikan; 
b. Karena kurangnya keterampilan dan pengetahuan para pengelola kredit.

c. Karena lemahnya organisasi dan manajemen bank yang bersangkutan;

d. Tidak adanya kebijakan kredit dan prosedur pemberian yang lengkap, jelas dan akurat pada bank;

e. Kurangnya monitoring dan pengawasan kredit yang dilakukan oleh bank yang bersangkutan kepada para debiturnya;

f. Karena kondisi ekonomi dan keuangan yang memburuk;

g. Adanya persaingan yang tajam diantara perbankan sendiri.

Kredit macet dapat disebabkan juga oleh faktor internal dan eksternal :

1. Penyebab faktor internal, meliputi :
a. Adanya kebijakan kredit yang ekspansif.
b. Penyimpangan dalam pelaksanaan prosedur pemberian kredit.
c. Itikad kurang baik dari pihak Bank.
d. Lemahnya sistem administrasi dan pengawasan kredit.
e. Lemahnya sistem informasi kredit.

2. Penyebab faktor eksternal :
a. Menurunnya kegiatan ekonomi dan tingginya suku bunga kredit.
b. Pemanfaatan iklim persaingan perbankan yang tidak sehat oleh debitor.
c. Kegagalan usaha debitor.
d. Debitor mengalarni musibah.

Banyak faktor yang menyebabkan terjadinya kredit macet dan tidak kalah dominannya adalah disebabkan karena adanya kolusi, baik kolusi bilateral antara pejabat bank dengan nasabah, maupun kolusi tripartit, yakni antara nasabah, pejabat bank dan oknum-oknum pemerintah lewat referensi atau telepon sakti. Faktor degradasi mentalitas banyak memainkan peran penting sehingga terjadinya kredit macet.

Istilah kredit itu sendiri adalah kepercayaan, yang berarti manakala seseorang mendapatkan kredit berarti telah mendapatkan kepercayaan dari bank. Oleh karena itulah dapat dikatakan bahwa inti dari kredit adalah kepercayaan. Kepercayaan inilah sebagai suatu unsur yang harus dipegang yang menjadi benang merah melintasi falsafah perkreditan dalam arti sebenarnya, bagaimanapun bentuk, macam dan ragamnya dan dari manapun asalnya, serta kepada siapapun ia diberikan. Dengan demikian dalam pemberian kredit banyak muatan-muatan yang bersifat penilaian terhadap pribadi debitur, di samping penilaian dari aspek ekonomis.

Berdasarkan ketentuan dalam UU Perbankan tersebut di atas, maka ketentuan-ketentuan hukum tentang masalah perkreditan ini meliputi aspek batasan pengertian kredit, jaminan pemberian kredit (keharusan analisa $5 \mathrm{C}$ ), batas maksimum pemberian kredit, pembatasan kredit untuk hal-hal tertentu, dan penyelesaian terhadap kredit macet.

\section{PENERAPAN PRINSIP KEHATI-HATIAN DAN MANFAATNYA TERHADAP PERBANKAN}

Manfaat utama yang dapat diperoleh dalam penerapan prinsip kehati-hatian dalam kegiatan operasional bank, meliputi: (1) Bagi bank pelaksana, (2) Manfaat bagi nasabah bank, (3) Manfaat bagi pemerintah. Manfaat-manfaat tersebut dapat dijelaskan sebagai berikut :

\section{Manfaat Bagi Bank Pelaksana}

Dalam melaksanakan kegiatan operasional perbankan di Indonesia, diatur melalui UU No. 7 Tahun 1992 tentang Perban-kan sebagaimana telah diubah dengan UU No. 10 Tahun 1998. Menurut ketentuan tersebut, perbankan mempunyai peran yang strategis dalam pelaksanaan pembangunan nasional. Peranan yang strategis tersebut terutama disebabkan oleh fungsi utama bank sebagai wahana yang dapat menghimpun dan menyalurkan dana masyarakat secara efektif dan efisien. 
Dalam rangka meningkatkan peranan bank yang strategis tersebut, dengan diundangkannya UU No. 10 Tahun 1998 tentang tentang Perbankan, telah dilakukan penyempurnaan tata laksana perbankan dengan langkah-langkah antara lain :

1. Penyederhanaan jenis bank, menjadi Bank Umum dan Bank Perkreditan Rakyat, serta memperjelas ruang lingkup dan batas kegiatan yang dapat diselenggarakan oleh bank

2. Persyaratan pokok untuk mendirikan suatu bank diatur secara rinci, sehingga ketentuan pelaksanaan yang berkaitan dengan pendirian dan kegiatan perbankan menjadi lebih jelas dan terarah.

3. Peningkatan perlindungan dana masyarakat yang dipercayakan kepada lembaga perbankan melalui penerapan prinsip kehati-hatian dan pemenuhan ketentuan mengenai kesehatan bank.

4. Peningkatan profesionalisme para pelaku dibidang perbankan

5. Perluasan kesempatan untuk menyelenggarakan kegiatan dibidang perbankan secara sehat dan bertanggung jawab, sekaligus mencegah terjadinya praktik-praktik yang merugikan kepentingan masyarakat luas.

Keadaan ekonomi nasional dewasa ini menunjukan arah yang semakin menyatu dengan ekonomi regional dan internasional. Sementara itu perkembangan perekonomian nasional senantiasa bergerak cepat dengan tantangan yang semakin kompleks. Oleh karena itu diperlukan berbagai penyesuaian kebijakan di bidang ekonomi termasuk sektor perbankan yang diharapkan akan dapat memperbaiki dan memperkokoh perekonomian. Sejalan dengan itu, penyempurnaan sektor perbankan yang memiliki posisi strategis sebagai lembaga penunjang sistem pembayaran, merupakan hal yang sangat penting.
Bank merupakan simbol kepercayaan masyarakat terhadap kondisi moneter di Indonesia. Oleh sebab itu jika suatu bank mengalami kondisi sakit maka kepercayaan masyarakat menjadi berkurang dan hal ini dapat menimbulkan pengaruh yang sangat signifikan bagi perekonomian negara. Karenanya bank sebagai industri jasa yang melayani konsumen dalam arti seluasluasnya, baik konsumen antara maupun konsumen akhir harus dikelola berdasarkan prinsip kehati-hatian (prudential principle).

Dengan memperhatikan prinsip kehatihatian itu maka diharapkan perbankan Indonesia dalam melakukan usahanya akan melindungi kepentingan masyarakat penyimpan dana khususnya serta menunjang kegiatan ekonomi pada umumnya, bahkan lembaga perbankan diharapkan dituntut mampu menciptakan stabilitas nasional dalam arti yang seluasluasnya.

Dalam praktik perbankan dapat timbul dugaan adanya kemungkinan kecurangankecurangan yang berupa kelemahan dalam dunia perbankan, yang tentunya akan dapat merugikan masyarakat. Kemungkinan adanya penyimpangan yang dilakukan oleh bank tersebut dapat saja terjadi, mengingat bank adalah lembaga yang bergerak di bidang keuangan, yang secara naluri alamiah menjadi tempat yang menarik bagi mereka yang beritikad tidak baik dalam mengelola kehidupan bank. Oleh karena di samping sarana lain, seperti etik dan moral perbankan, juga perlu sarana hukum yang secara tegas dapat menindak terhadap berbagai tindak penyimpangan yang dilakukan oleh oknum-oknum tertentu, yang merugikan citra bank dan dapat menghancurkan bank tersebut, bahkan memiliki dampak negatif terhadap bank-bank lainnya.

Undang-undang Nomor 7 Tahun 1992 yang telah diubah dengan Undang-undang Nomor 10 Tahun 1998, sangat 
menekankan bahwa bank harus melaksanakan usahanya dengan menggunakan prinsip kehati-hatian (prudential principle) undang-undang ini demikian tegas menghendaki agar supaya bank-bank secara benar menerapkan prinsip kehati-hatian dalam usahanya sampai undang-undang perbankan ini menganggap perlu untuk mengklasifikasikan sebagai tindak pidana.

Penerapan prinsip kehati-hatian dalam kegiatan operasional bank adalah dalam rangka memberikan perlindungan terhadap rnasyarakat dalam hal ini nasabah. Hal ini mengingat dana masyarakat yang ada pada bank tersebut, merupakan modal utama dari bank dalam menjalankan usahanya, karena itu agar bank dapat memperoleh modalnya dari masyarakat, maka bank tersebut harus dipercaya (asas kepercayaan) oleh masyarakat, dan untuk dapat dipercaya tentunya bank harus dapat membuktikan bahwa dirinya sehat (asas kesehatan bank), dan untuk dapat sehat berarti bank tersebut harus bekerja secara hati-hati (menerapkan prinsip kehati-hatian) dalam menggunakan dana masyarakat.

Seperti disebutkan di atas, prinsip kehatihatian bank adalah prinsip yang melandasi perilaku bank dalam melakukan aktivitasnya. Aktivitas bank tersebut dapat terdiri dari kegiatan dibidang pasiva (transaksi pasif), yaitu berupa usaha menghimpun dana, kegiatan dibidang aktiva (transaksi aktif), yaitu usaha menyalurkan dana, dan kegiatan lain (jasa perbankan) misalnya bank garansi. Dengan demikian dalam kerangka menjalankan kegiatan itulah bank berpegang pada prinsip kehati-hatian.

Pada sisi yang lain untuk terciptanya bank yang sehat, menghendaki adanya suatu keadaan atau kondisi bank yang memenuhi standar kelangsungan hidup bank yang tidak dihinggapi suatu penyakit berupa kesalahan manajemen yang dapat membahayakan kehidupan bank itu sendiri. Sehingga asas kesehatan ini bergerak (dari sakit ke sehat atau sebaliknya) ditentukan oleh aktivitas yang dilakukan oleh bank itu sendiri. Secara ideal tentunya tidak mungkin bank melakukan aktivitas yang membuat dirinya sakit, akan tetapi dalam kenyataannya ada saja aktivitas yang dilakukan yang secara sadar atau tidak sadar akan membuat bank itu menjadi sakit. Apabila bank tersebut sakit dan tidak dapat memenuhi kewajibannya kepada pihak ketiga atau kepada nasabahnya, maka akan menghilngkan kepercayaan masyarakat terhadap bank tersebut.

\section{Manfaat Terhadap Nasabah Bank}

Nasabah merupakan pihak pertama yang sangat berkepentingan terhadap bank, baik dalam kerangka mengambil keuntungan dari simpanan uangnya terhadap bank untuk nasabah penyimpan dana, maupun mengambil keuntungan meminjam uang dari bank bagi nasabah debitur. Di samping itu juga kepentingan akan jasa jasa lainnya yang dilakukan oleh bank pada saat ini.

Dilihat dari kepentingan yang seperti itu, terdapat dua sisi yang saling berkaitan, yaitu sisi kepentingan nasabah terhadap bank dan sisi kepentingan bank terhadap nasabah, sehingga dalam rangka menciptakan suatu bank yang sehat, maka sisi nasabah dan sisi bank mempunyai peranan yang sama.

Penerapan prinsip kehati-hatian pada dasarnya adalah dalam kerangka menjembatani kedua sisi kepentingan tersebut, baik itu kepentingan bank maupun kepentingan nasabah yang sama-sama mengharapkan adanya keuntungan dalam keterlibatan mereka sebagai pelaku dalam kegiatan perbankan. Khusus bagi nasabah penyimpan dana, maka keberadaan asas kehati-hatian dan kesehatan bank tersebut adalah justru dalam rangka melindungi dana yang mereka simpan pada bank.

Dengan demikian penerapan prinsip kehati-hatian mengandung makna bagi 
nasabah, yaitu sebagai pedoman bagi mereka untuk tetap menjalin hubungan kepercayaan dengan pihak bank. Di samping itu bagi nasabah penerapan prinsip kehatihatian ini bermakna, sebagai dasar untuk mengajukan tuntutan atas kerugian yang diderita dalam menjalin hubungan dengan bank.

Mengingat betapa pentingnya penerapan prinsip kehati-hatian dengan tujuan untuk menciptakan bank yang sehat tersebut, terutama terhadap pihak-pihak yang terlibat dalam dunia perbankan, maka secara keseluruhan keberadaan prinsip tersebut mempunyai makna tolak ukur dalam usaha menciptakan sistem perbankan yang sehat. Dengan kata lain, baik tidaknya penilaian orang terhadap sistem perbankan nasional, adalah dilihat bagaimana implementasi prinsip kehati-hatian dalam kegiatan operasional bank, dan tentunya akan dilihat pula bagaimana implementasinya dalam praktek kehidupan perbankan yang sehat.

Bagi masyarakat luas, prinsip kehatihatian bank mempunyai makna tersendiri, yaitu menjadi dasar pertimbangan untuk menentukan menjadi nasabah suatu bank atau tidak, dengan kata lain prinsip ini mempunyai makna kepercayaan. Artinya tumbuh tidaknya kepercayaan masyarakat terhadap dunia perbankan, akan diukur dari impelementasi prinsip kehati-hatian dalam kehidupan dunia perbankan.

\section{Manfaat Bagi Pemerintah}

Pada perkembangan sejarah perbankan di Indonesia, kenyataan menunjukkan bahwa industri perbankan di Indonesia mendapat perhatian utama dari pemerintah, dan merupakan industri yang paling banyak diatur oleh pemerintah. Hal ini disebabkan karena dalam kegiatan operasional perbankan lebih banyak tergantung kepada dana masyarakat, sehingga perlu dijamin kepastian keamanannya.
Penyaluran dana-dana masyarakat tersebut dilakukan melalui pemberian kredit atau melalui pembelian surat-surat berharga yang merupakan sebuah bisnis yang beresiko tinggi, yang apabila tidak dikelola dengan baik, dapat mengganggu tidak hanya kelangsungan usaha bank itu, akan tetapi dapat juga berpengaruh terhadap sistem perbankan dan kestabilan moneter.

Manfaat bagi pemerintah dalam pengaturan perbankan yaitu meliputi :

1. Tujuan stabilitas moneter mengingat masih dominannya perbankan sebagai sumber pembiayaan investasi.

2. Fungsi pengawasan dalam rangka menjaga keamanan dan kesehatan bank maupun sistem keuangan secara keseluruhan, agar tercipta praktek perbankan dan persaingan antar bank yang sehat. Selain itu, untuk melindungi nasabah dan menjaga stabilitas pasar uang, mendorong sistem perbankan yang efisien dan kompetitif dan tanggap terhadap kebutuhan masyarakat akan jasa keuangan yang berkualitas dengan biaya yang wajar.

3. Tujuan pencapaian program-program pembangunan, khususnya ikut mengatasi masalah-masalah ekonomi seperti tingginya angka pengangguran, kemiskinan, atau kelangkaan sumbersumber dana investasi.

Bank diperbolehkan membuka rahasia atau member keterangan mengenai nasabahnya, apabila untuk kepentingan yang mendesak, misalnya untuk kepentingan Negara atau kepentingan hokum. ${ }^{14}$

Sesuai UU Bank Sentral, yaitu UU No. 3 Tahun 2004 tentang Perubahan UU No. 23 Tahun 1999 tentang Bank Indonesia, maupun UU No. 10 Tahun 1998 tentang

\footnotetext{
14 Hermansyah, Hukum Perbankan Nasional Indonesia, Kencana, Jakarta, 2005, hlm. 111.
} 
Perubahan UU No.7 tahun 1992 tentang Perbankan, bank-bank di Indonesia mengemban peran sebagai agen pembangunan (agent of development) dan diharapkan dapat memberikan kontribusi pada usaha-usaha peningkatan tabungan nasional, menumbuhkan kegiatan usaha serta meningkatkan alokasi sumber-sumber perekonomian.

UU Bank Sentral, yaitu UU No. 3 Tahun 2004 tentang Perubahan UU No. 23 Tahun 1999 tentang Bank Indonesia menetapkan Bank Indonesia sebagai bank sentral sebagaimana kedudukan dan fungsinya yang ditetapkan oleh UU No. 3 Tahun 2004. Pada dasarnya tujuan Bank Indonesia adalah mencapai dan memelihara kestabilan nilai rupiah dan untuk mencapai tujuannya maka Bank Indonesia mempunyai tugas menetapkan dan melaksanakan kebijakan moneter, mengatur dan menjaga kelancaran sistem pembayaran, mengatur dan mengawasi bank. Khusus dibidang perbankan.

Bank Indonesia adalah institusi yang bertanggung jawab terhadap pembinaan dunia perbankan nasional. Oleh karena pada dasarnya setiap bank harus taat kepada Bank Indonesia, wewenang Bank Indonesia sebagai pengawas dan pembina perbankan Indonesia sangatlah luas.

Sebagai pihak yang bertanggung jawab terhadap pembinaan perbankan nasional, Bank Indonesialah yang menetapkan ketentuan-ketentuan tentang solvabilitas dan likuiditas bank, serta memberikan bimbingan kepada bank guna penatalaksanaun bank yang sehat. Oleh karena itu secara otomatis pula Bank Indonesia yang mengawasi kehidupan dunia perbankan nasional.

Dengan kedudukannya yang seperti ini, berarti Bank Indonesia adalah pihak yang sangat berkepentingan terhadap terciptanya kondisi sistem perbankan yang sehat. Dalam kerangka untuk menciptakan sistem perbankan yang sehat tersebut, maka Bank
Indonesia memerlukan sarana. Sarana ini kalau dikaitkan dengan mekanisme bank yang terjalin antara Bank Indonesia dengan bank dan dengan nasabah, adalah dengan cara mengembangkan pola hubungan ketiga pihak tersebut, agar tercipta suatu hubungan yang harmonis dalam dunia perbankan. Implementasi pengembangan pola hubungan tersebut adalah dengan melalui sarana asas-asas hubungan yang secara khas melekat dalam kehidupan dunia perbankan.

Penerapan prinsip kehati-hatian dan kesehatan bank itu sendiri dapat dibina dan dikembangkan oleh Bank Indonesia melalui norma-norma perbankan secara umum (termasuk etika dan moral perbankan), maupun secara khusus dituangkan melalui perangkat hukum. Pembinaan dan pengembangan melalui perangkat hukum inilah yang menjadi rambu-rambu hukum, yakni rambu-rambu hukum asas kehatihatian dan kesehatan bank yang termuat dalam berbagai peraturan hukum dibidang perbankan tersebut. Dengan demikian Bank Indonesia terhadap prinsip kehati-hatian dan kesehatan bank tersebut mernpunyai makna sebagai dasar dan atau pedoman dalam melakukan pembinaan dan pengawasan terhadap kehidupan perbankan.

Berbeda dengan kedudukan Bank Indonesia di atas, bank sebagai suatu Badan Usaha adalah berperan sebagai pelaku dalam kehidupan perbankan. Dengan kata lain bank ini adalah subjek atau pelaku dalam kehidupan perbankan, karenanya la menjadi objek pembinaan dan pengawasan dari Bank Indonesia. Sebagai pelaku dalam kehidupan perbankan menjadikan posisi bank menempati posisi sentral yang sangat menentukan hitam putihnya kehidupan dunia perbankan.

Berkaitan dengan kapasitas bank sebagai pelaku inilah, sejak kelahirannya, kehidupannya sampai kepada kematiannya (likuidasi) tidak bisa terlepas dari norma- 
norma kehidupan yang mengatur kehidupan dunia perbankan. Dalam hal ini berarti penerapan prinsip kehati-hatian dan kesehatan bank itu sendiri adalah prinsip yang melekat pada dirinya dalam kerangka kehidupan suatu bank.

\section{PENUTUP}

\section{A. KESIMPULAN}

1. Bank dalam kegiatan operasional perbankannya harus menerapkan prinsip kehati-hatian (prudential banking) dimana prinsip kehatihatian dalam mengelola dan menjalankan aktivitas perbankan sehari-hari, bertujuan untuk menjaga kesehatan bank. Hal ini harus dilakukan mengingat bank merupakan lembaga kepercayaan masyarakat, dan berfungsi untuk menjaga kestabilan moneter suatu negara melalui transaksi keuangan yang sehat pada perbankan.

2. Implementasi prinsip kehati-hatian yang diatur melalui UU Perbankan keberadaannya dalam UU No. 7/1992 dan perubahannya yaitu UU No.10/1998 tentang Perbankan, telah diatur secara tegas: Aspek dasar (Pasal 2); Aspek ketentuan perkreditan (Pasal 8, 11); Aspek perijinan, bentuk hukum dan kepemilikan bank (Pasal 16 s.d Pasal 28); Aspek pembinaan dan pengawasan Bank Indonesia (Pasal 29 s.d Pasal 37). Sedangkan Implementasi prinsip kehati-hatian dalam aspek perkreditan dapat dilihat pada : Pasal 1 angka (11) tentang pengertian kredit; Pasal 8 tentang pemberian kredit atau pembiayaan berdasarkan prinsip syariah dengan kewajiban menganalisis dengan prinsip perkreditan; Pasal 11 tentang batas maksimum pemberian kredit (BMPK); disamping itu beberapa ketentuan lain dalam pelaksanaan pemberian kredit, yaitu ketentuan dari proses pemberian kredit sampai kepada upaya mengatasi kredit yang mengalami kemacetan.

3. Manfaat dengan diterapkannya prinsip kehati-hatian bank, yaitu: (1) Bagi bank pelaksana, dalam melakukan usahanya akan melindungi kepentingan nasabah penyimpan dana khususnya, dapat memberikan pelayanan jasa perbankan yang cepat, murah dan aman sehingga akan meningkatkan kepercayaan masyarakat terhadap bank tersebut sebagai bank yang benar-benar prudent dan solid; (2) Manfaat bagi nasabah, yaitu nasabah dapat memperoleh pelayanan jasa perbankan yang aman, cepat dan menguntungkan bagi transaksinya disamping nasabah akan terbebas dari perasaan was-was, akan nasib simpanannya akibat ditutupnya bank; (3) Manfaat bagi pemerintah; untuk stabilitas moneter mengingat masih dominannya perbankan sebagai sumber pembiayaan investasi, menjaga keamanan dan kesehatan bank maupun sistem keuangan secara keseluruhan, agar tercipta praktek perbankan dan persaingan antar bank yang sehat, melindungi nasabah dan menjaga stabilitas pasar uang, mendorong sistem perbankan yang efisien dan kompetitif dan tanggap terhadap kebutuhan masyarakat akan jasa keuangan yang berkualitas dengan biaya yang wajar, dan untuk pencapaian program-program pembangunan.

\section{B. SARAN}

Mengingat bank sebagai lembaga kepercayaan masyarakat, dan sangat sensitif terhadap informasi negatif terhadap praktik penyimpangan bank, maka sebaiknya pihak direksi, komisaris maupun karyawan bank dalam menjalankan usaha bank, harus menerapkan prinsip kehati-hatian bank, termasuk dalam hal pengelolaan dana 
nasabah, sehingga bank akan mampu membayar kembali dana tersebut pada saat akan diambil pemiliknya. Hal ini bertujuan untuk menjaga kepercayaan masyarakat terhadap bank, dan lembaga perbankan.

\section{DAFTAR PUSTAKA}

Asikin, Pokok-Pokok Hukum Perbankan, PT. Raja Grasindo Persada, Jakarta, 1995.

Black Henry Campbell Black, Black's Law Dictionary, St.Paul Minn, Sixth Edition, 1990.

Hermansyah, Hukum Perbankan Nasional Indonesia, Kencana, Jakarta, 2005.

Iswardono Sp, Uang dan Bank, BPFE Yogyakarta, 1994.

John Echols. M dan Shadily Hassan, Kamus Inggris Indonesia, PT Gramedia Pustaka Utama, Jakarta. 1997.

Kasmir, Bank \& Lembaga Keuangan Lainnya, PT. Raja Grafindo Persada, Jakarta, 2002.

Moekidjat, Kamus Manajemen, Mandar Maju, Bandung, 1990.

Muhammad Djumhan, Hukum Perbankan di Indonesia, PT. Citra Aditya Bakti, Bandung, 1993.

Putra Edy Mgs The Aman, Kredit Perbankan Suatu Tinjauan Yuridis, Liberty, Yogyakarta, 1986.

Soepraptomo Heru, Analisis Ekonomi Terhadap Hukum Perbankan, Jurnal Hukum Bisnis, Vol. 1, 1997.

Sukrisno, Perencanaan Strategi Bank, Lembaga Pengem-bangan Perbankan Indonesia, Djambatan, Jakarta, 1992.

Sutan Remy Sjahdeini, Kebebasan Berkontrak dan Perlindungan Yang Seimbang Bagi Para Pihak Dalam Perjanjian Kredit Bank Di Indonesia, Institut Bankir Indonesia, Jakarta. 1993.

Syahputra Iman, T. Arif Djohan T, dan Amin Widjaja, Peraturan Perundangundangan Perbankan Di Indonesia 19971998, Harvarindo, 1999.
Thomas Suyatno, Chalik, H.A., Sukada Made, Ananda C.T.Y. Marala, D.T. Dasardasar Perkreditan, PT. Gramedia Pustaka Utama, Jakarta, 1993.

Widjanarto, Hukum Dan Ketentuan Perbankan Di Indonesia, PT. Pustaka Utama Grafiti, Jakarta, 1994.

Zulkarnain Sitompul, Penjaminan Dana Nasabah Bank, Jurnal Hukum Bisnis, No. 22, 2003. 